J. Product. \& Dev., 15(2): 163 - 184(2010)

\title{
SOME PHYSIOLOGICAL PRODUCTIVE AND REPRODUCTIVE TRAITS OF INSHAS LOCAL STRAIN AS AFFECTED BY DIETARY ZINC SUPPLEMENTATION UNDER HOT SUMMER CONDITIONS IN EGYPT
}

\author{
A.M.A. Bealish"; W. Ezzat"; S.M.M. Mousa*, H.A.H. Abd-El-Halim ${ }^{*}$ and M.S. \\ Shoeib \\ Poultry Breeding Department, Animal Production Research Institute, Agriculture \\ Research Center, Egypt * \\ Poultry Nutrition Department, Animal Production Research Institute, Agriculture \\ Research Center, Egypt **
}

\section{ABSTRACT:}

A $2 X 4$ factorial design experiment was performed including two sources of zinc (inorganic or organic). The inorganic $Z n$ was provided as zinc oxide $72 \%$ and organic Zn was provided as Bioplex $\mathrm{Zn}$, a chelated $\mathrm{Zn}$ proteinate that contained 10\% Zn (Bioplex, Alltech Inc). The inorganic or organic zinc were added to the basal diet containing $22.21 \mathrm{mg}$ zinc $/ \mathrm{Kg}$ diet completed to 35(NRC, 1994), 70, 105 and $140 \mathrm{mg} \mathrm{Zn} \mathrm{/} \mathrm{Kg} \mathrm{diet.} \mathrm{A} \mathrm{total}$ number of 240 laying hens and 24 cocks of Inshas strain (local strain) of 24 weeks old was used to study the effect of sources and levels of $\mathrm{Zn}$ addition to birds rations on their productive performance, reproductive traits, immune response to SRBC and economic efficiency. Birds were randomly distributed into eight equal groups (30 hens and 3 cocks each). Each group was subdivided into three replicates (10 hens and 1 cocks each) laying hens of each group nearly equal in average body weight (1430.55 \pm 19.95$)$ and average daily egg production. The experiment period extended from 24 to 36 weeks of age, during hot summer season (from June to September, 2008). The average minimum and maximum ambient temperatures ranged between 23.6 and $34.7^{\circ} \mathrm{C}$, relative humidity from 31.8 to $80.7 \%$ and temperature-humidity index (THI) from 21.64 to $33.52 \%$ under Inshas, Sharkia Province, Egypt.

Results obtained showed that feed conversion, egg production\%, egg mass (24 - 28 weeks of age), semen ejaculate volume ( $\mathrm{ml}$ ), percentages of sperm motility and sperm-cell concentration and antibody titer against $S R B C$ 'S were improved significantly $(P<0.05)$, while dead spermatozoa $(\%)$ were decreased significantly $(P<0.05)$ for birds fed diets 
contained organic zinc as compared to those fed zinc oxide. Laying hens fed diets contained $105 \mathrm{mg} \mathrm{Zn} / \mathrm{Kg}$ diet recorded best values of feed conversion, egg production(\%), egg mass, fertile eggs (\%), hatchability/total eggs (\%) and hatchability/ fertile eggs (\%) values while the lowest values were recorded with layers fed diets containing $35 \mathrm{mg} Z \mathrm{Zn}$ oxide /Kg diet. Inshas cocks fed 105 mg Bioplex Zn / Kg diet showed the highest sperm cell concentration and lowest in dead sperm percentages as compared with other treatment groups which, improved the positive and direct effect on the viability of sperm and consequently affect the rate of cock fertility. Heamoglobin, serum zinc and yolk zinc were higher (al most significantly) for layers fed diets contained at levels 105 or $140 \mathrm{Zn} \mathrm{mg/} \mathrm{Kg}$ as compared with those fed other levels of Zn at the end of experimental period. Generally, zinc from Bioplex Zn improved titer against SRBC'S better than zinc from Zn oxide.

In conclusion, diets supplemented with organic zinc at the level of $105 \mathrm{mg} \mathrm{Zn} / \mathrm{Kg}$ diet improved most physiological productive and reproductive traits of Inshas strain under hot summer condition in Egypt.

Key words: $\mathrm{Zn}$ oxide, Bioplex $\mathrm{Zn}$, productive \& reproductive traits, immune response to SRBC, economic efficiency.

\section{INTRODUCTION}

High ambient temperatures compromise performance and productivity through reducing feed intake and decreasing nutrient utilization, growth rate, egg production, egg quality, and feed efficiency, which lead to economic losses in poultry production (Donkoh, 1989). Environmental stress, also leads to oxidative stress associated with a reduced antioxidant status in the bird, as reflected by increased oxidative damage and lowered plasma concentrations of antioxidant vitamins (e.g., vitamins E, A, and C) and minerals (e.g., Zn), Franco and Beck (2007) and Sahin et al. (2009). Supplemental zinc used in poultry diets is beneficial to layer hens during environmental stress (Sahin and Kucuk, 2003). Zinc has an important role in numerous biological processes in avian and mammalian species. For instance, $\mathrm{Zn}$ is an essential component of many enzymes, and it has both structural and catalytic functions in metalloenzymes (Innocenti et al., 2004). Furthermore, dietary $\mathrm{Zn}$ is required for normal immune function, as well as proper skeletal development and maintenance, Kidd et al. (1992 and 2000). Sahin et al., (2009) reported that one of the most important functions of $\mathrm{Zn}$ is related to its antioxidant role and its participation in the antioxidant defense system . Published research relative to the interactions between heat stress and Bioplex (organic) $\mathrm{Zn}$ in 
poultry is sparse. Adverse effects of heat stress on $\mathrm{Zn}$ metabolism caused to increase $\mathrm{Zn}$ excreted in poultry manure. Dietary modifications are among the most preferable and practical methods to alleviate the effect of high environmental temperature on poultry performance and such methods have previously been used. Organic Zn sources such as Bioplex Zn , Zn-methionine or Zn-propionate were more bioavailable than inorganic $\mathrm{Zn}$ sources such as zinc oxide $(\mathrm{ZnO})$ or zinc Sulfate (ZnSO4-H2O) (Wedekind et al., 1992; Hahn and Baker, 1993). Luecke et al., (1978) revealed that $\mathrm{Zn}$ has been reported to be involved in boosting the immune system to disease outbreaks. Subsequent research provided evidence for Nutrient Requirements for Poultry (NRC, 1994) to set the requirements of layer hens at $35 \mathrm{ppm}$. Another mode of action proposed for $\mathrm{Zn}$ as an antioxidant is its interaction with vitamin $\mathrm{E}$, because vitamin $\mathrm{E}$ status is impaired in zinc-deficient animals (Salgueri, et al., 2000). Rashidi et al.(2010) found that heat stress decreased humoral and cell-mediate immune response and diet supplementation with vitamin $\mathrm{E}$ and $\mathrm{Zn}$ decreased the impact of heat stress on performance and immune system of broilers.

On the other hand, organic mineral sources such as proteinate and amino acid chelate have been used increasingly in the last years due to their higher bioavailability (Cao et al., 2000) and lower manure loading (Manon et al., 2005). In general, inconsistency exists among research results regarding bioavailability of organic $\mathrm{Zn}$ sources. Moreover, some studies indicated small or no differences in bioavailability of Zn sources either inorganic or organic (Ammerman et al., 1995). This work compiles past and present information about the role of $\mathrm{Zn}$ in heatstressed poultry health. This study was carried out to establish the value of $\mathrm{Zn}$ (source and level) on productive and reproductive performance in heat stressed laying hens. Also, some blood hematological and biochemical parameters, semen characteristics, immune response to sheep red blood cells (SRBC'S) and economical efficiency with different sources and levels of zinc were studied.

\section{MATERIALS AND METHODS}

The experimental work of this study was carried out at Inshas Poultry Research Station, Animal Production Research Institute, Agriculture Research Center, Giza, Egypt, during hot summer season (from June to September, 2008). The average minimum and maximum ambient temperatures ranged between 23.6 and 34.7 0C, relative humidity from 31.8 to $80.7 \%$ and temperature-humidity index (THI) from 21.64 to 33.52\%, under Inshas, Sharkia Province, Egypt (Table 1). THI was estimated according to the formula by Marai et al. (2000) as follows: 
Table (1). Microclimatic data during the whole experimental period, under environmental condition.

\begin{tabular}{|c|c|c|c|c|c|c|}
\hline \multirow[t]{2}{*}{$\begin{array}{l}\text { Summer } \\
\text { months }\end{array}$} & \multicolumn{2}{|c|}{$\begin{array}{c}\text { Averages temperature } \\
\left({ }^{0} \mathrm{C}\right)\end{array}$} & \multicolumn{2}{|c|}{$\begin{array}{c}\text { Averages } \\
\text { RH (\%) }\end{array}$} & \multicolumn{2}{|c|}{$\begin{array}{l}\text { Averages } \\
\text { (THI) }\end{array}$} \\
\hline & $\operatorname{Min}^{*}$ & $\operatorname{Max}^{* *}$ & $\operatorname{Min}^{*}$ & $\operatorname{Max}^{* * *}$ & $\operatorname{Min}^{*}$ & $\operatorname{Max}^{* * *}$ \\
\hline June & $22.5 \pm 0.37$ & $35.0 \pm 0.40$ & $25.7 \pm 1.11$ & $75.5 \pm 1.66$ & $r \cdot .7 r$ & Tr. \\
\hline July & $23.7 \pm 0.21$ & $34.1 \pm 0.29$ & $34.7 \pm 1.08$ & $83.1 \pm 1.16$ & rI.Ar & V. \\
\hline August & $\cdot r l \pm r \leqslant .0$ & $\cdot r r_{ \pm} r_{0} .1$ & $1.1 \leqslant \pm r \leqslant . q$ & $\left.\cdot .9 r_{ \pm} \wedge r.\right\urcorner$ & $r Y . \leqslant T$ & $r \varepsilon .0$ \\
\hline Averages & $23.6 \pm 0.17$ & $34.7 \pm 0.18$ & $31.8 \pm 0.78$ & $80.7 \pm 0.82$ & TI.T\& & Tr.OT \\
\hline
\end{tabular}

$\mathrm{THI}=\mathrm{db} \mathrm{b}^{0} \mathrm{C}-\left\{(0.31-0.31 \mathrm{RH})\left(\mathrm{db}^{0} \mathrm{C}-14.4\right)\right\}$, where $\mathrm{db}^{0} \mathrm{C}=$ bulb temperature in Celsius and $\mathrm{RH}=\mathrm{RH} \% / 100$. A $2 \mathrm{X} 4$ factorial design experiment was performed including two sources of $\mathrm{Zn}$ (inorganic or organic) and four levels (35, 70, 105 and $140 \mathrm{mg} \mathrm{Zn} / \mathrm{Kg}$ diet). The inorganic $\mathrm{Zn}$ was provided as $\mathrm{Zn}$ oxide $72 \%$ and organic $\mathrm{Zn}$ was provided as Bioplex $\mathrm{Zn}$, a chelated $\mathrm{Zn}$ proteinate, that contained $10 \% \mathrm{Zn}$ (Bioplex, Alltech Inc). The inorganic and organic zinc were added to the basal diet containing $22.21 \mathrm{mg} \mathrm{Zn} \mathrm{/} \mathrm{Kg} \mathrm{diet} \mathrm{and} \mathrm{completed} \mathrm{to} \mathrm{35(NRC,} \mathrm{1994),} \mathrm{70,} 105$ and $140 \mathrm{mg} \mathrm{Zn} \mathrm{/} \mathrm{Kg} \mathrm{diet.} \mathrm{The} \mathrm{composition} \mathrm{and} \mathrm{chemical} \mathrm{analysis} \mathrm{of} \mathrm{the} \mathrm{experimental}$ laying diet are presented in Table (2). A total number of 240 laying hens and 24 cocks of Inshas local strain at 24 weeks of age were randomly distributed into 8 treatment groups ( 30 hens and 3 cocks / each treatment). Each group was subdivided into three replicates (10 hens and 1 cock each). The experimental groups were, nearly equal in average body weight (1430.55 \pm 19.95 and average daily egg production.

The experimental period extended from 24 to 36 weeks of age. The experimental birds were leg-banded and housed in 24 pens and fed a basal diet containing $17.33 \%$ crude protein and $2722 \mathrm{Kcal} \mathrm{ME} / \mathrm{Kg}$ diet (Table 2). Birds were fed ad-libitum and fresh water was available all the time during the experimental period. The photoperiod during the experimental period was fixed at $16 \mathrm{~h}$. Individual body weight of laying hens was recorded at 24, 28, 32 and 36 weeks of age. While egg number and egg weight were recorded daily and feed intake was calculated weekly. Egg mass was calculated by multiplying egg number by average egg weight. Feed conversion (g feed/g egg mass) was also calculated. At 36 weeks of age, 60 eggs from each treatment were collected and incubated. After 
Table 2. Composition and chemical analysis of the experimental diet fed during the laying period.

\begin{tabular}{lc}
\hline Ingredients & $\%$ \\
\hline Yellow corn $(8.5 \%)$ & 63.14 \\
Soybean meal $(44 \%)$ & 27.10 \\
Limestone (CaCo3) & 7.60 \\
Di-calcium phosphate & 1.50 \\
Dl-Methionine 99\% & 0.06 \\
Salt (NaCl) & 0.30 \\
Vit + Min. premix* & 0.30 \\
\hline Total & $\mathbf{1 0 0 . 0 0}$ \\
\hline Chemical analysis:- & \\
a-Calculated analysis **:- & \\
Crude protein, \%. & 17.33 \\
ME, Kcal/Kg. & 2722 \\
Calcium, \% & 3.35 \\
Available phosphorus, \%. & 0.40 \\
Lysine, \%. & 0.88 \\
Methionine, $\%$ & 0.34 \\
Methionine + cystine \%. & 0.64 \\
Zinc (mg/Kg) & 22.21 \\
\hline b-Determined analysis ***:- & \\
Crude protein,\%. & 16.76 \\
Crude fiber,\%. & 4.15 \\
Ash \%. & 6.38 \\
\hline
\end{tabular}

* Vitamin and mineral premix: each $3 \mathrm{Kg}$ of vitamin and mineral premix (Special component from commercial source AGRIVET Co.) contains: Vit. A. 12000000 IU, Vit. $D_{3} 2000000 \mathrm{IU}$, Vit. $K_{3} 2000 \mathrm{mg}$, Vit. E10,000 mg, Vit. B $100 \mathrm{mg}$, Vit. B 5000 mg, Vit. $B_{6} 1500 \mathrm{mg}$, Vit. $B_{12} 10 \mathrm{mg}$, Biotin $50 \mathrm{mg}$, Choline chloride $250000 \mathrm{mg}$, Pantothenic acid $10000 \mathrm{mg}$, Nicotenic acid $3000 \mathrm{mg}$, Folic acid $1000 \mathrm{mg}$, Manganese $60000 \mathrm{mg}$, Iron $30000 \mathrm{mg}$, Selenium $100 \mathrm{mg}$, Copper $10000 \mathrm{mg}$, lodine $1000 \mathrm{mg}$, Cobalt $100 \mathrm{mg}$, Carrier $\left(\mathrm{Ca}_{3} \mathrm{CO}_{3}\right)$ add to $3 \mathrm{~kg}$.

** Calculated according to NRC (1994).

*** Determined according to the methods of AOAC (1990).

hatching, chicks were counted and non-hatched eggs were broken to determine the percentages of fertility and hatchability. Fertility\% was calculated as the percentage of fertile eggs from the total number of set eggs, while the hatchability\% was expressed as chicks hatched from fertile eggs and from total set eggs. Semen samples were individually collected ( 24 cocks) at the end of experiment using the abdominal massage method from all cocks. Semen ejaculate volume was measured 
in graduated tubes and hydrogen-ion concentration $(\mathrm{pH})$ was measured by Universal Indicator Paper and Standard Commercial Stain (Karras, 1952). Spermcell concentration was determined using the spectrophotometer density meter technique with diluted semen samples $(1: 250)$ as described by Lake and Stewart (1978). Eosin-Nigrosine stain was used to determine the percent of morphologically sperm abnormalities and dead spermatozoa (Lake and Stewart, 1978). A small droplet from cock semen was placed on a warm slide, covered with a cover slide and examined for sperm motility microscopically at 40x magnification.

Blood samples were collected, at the end of the experiment, from 3 hens per treatment $(5 \mathrm{ml} / \mathrm{hen})$ from the brachial vein and transferred into tube. Serum samples were obtained by centrifugation of samples at $-20^{\circ} \mathrm{C}$ until they were analyzed. No coagulated blood was used for hemoglobin determination. Stored serum samples were analyzed for total protein, albumin and zinc and yolk zinc using the suitable commercial chemical kits. Globulins were estimated by subtraction of albumin value from total protein value of each sample. At 34 weeks of age, nine birds from each treatment were immunized by intravenously injection with $1.0 \mathrm{ml}$ of suspension of sheep red blood cells (SRBC'S) 7\% in sterile saline (Yamamoto and Glick, 1982). Seven days following antigen challenge, blood samples were collected. Approximately $2.0 \mathrm{ml}$ of blood was drawn from the brachial vein of each bird. It was allowed to clot to provide serum for antibody titer. Humoral immune response to SRBC'S was measured using micro haemagglutination technique.

The economical efficiency (EEf) of the experimental treatments was estimated depending on feeding cost and price of egg produced.

The data pooled through the experiment were proceed by General Linear Model procedures (GLM) described in SAS User's Guide (SAS, Institute, 2003). Differences among treatment means were separated by Duncan's new multiplerange test (Duncan, 1955).

\section{RESULTS AND DISCUSSION}

\section{Productive performance:}

Results in Table (3) showed that body weight, feed intake and egg weight of laying hens were not significantly affected by dietary $\mathrm{Zn}$ during all the experimental periods. These results are in agreement with those obtained by Kout El-Kloub Moustafa et al. (2004) who reported that, the addition of $\mathrm{Zn}$ in laying hen diets either as $\mathrm{ZnO}$ or $\mathrm{Zn}$-methionine resulted in no significant differences in 
average body weight. Namra et al. (2008) found that quails fed dietary Zn (either $\mathrm{Zn} \mathrm{SO} 4$, imported zinc-methionine or local zinc-methionine) had an insignificantly improvement on body weight, as compared to those of the control group at 6 weeks of age. However, feed conversion during $24-28$ and 24-36 weeks of age, egg production and egg mass during $24-28$ weeks of age were significantly $(\mathrm{P}<0.05)$ improved when laying hens were fed organic zinc ( Bioplex Zn) compared with those fed inorganic zinc ( zinc oxide) under heat summer stress. These results are in full agreement with results of Ferket et al. (1992) who found that, dietry Zn-Met improved feed conversion ratio turkey toms than inorganic zinc. Also, Abou ElWafa et al., (2003) concluded that properly, supplemental Zn-methionine to the control diet significantly $(\mathrm{P}<0.05)$ increased body weight gain and improved feed conversion broiler chicks.

Zinc level had no significant effect on body weight, feed intake and egg weight of layers during all the experimental period (Table 3). Similar results were the obtained by El-Husseiny et al. (2008) who found that, the different levels of Zn (70, 105,140 and $175 \mathrm{mg} / \mathrm{Kg}$ diet) had no significant effect on egg weight of laying hens. Kim and Patterson (2005) found that diet supplemented with zinc $(1000,2000$ or 3000 ppm) had no significant effect on body weight, egg weight and feed consumption of hens. However, feed conversion, egg production and egg mass were improved with increasing zinc level from 35 to 70,105 or $140 \mathrm{mg} \mathrm{Zn}$ $/ \mathrm{Kg}$ diet in laying hen diets during all experimental periods (except at 32-36 weeks of age). However, the improvement was more pronounced and significant $(\mathrm{P}<0.05)$ with the $105 \mathrm{mg} \mathrm{Zn} \mathrm{/Kg} \mathrm{diet.} \mathrm{These} \mathrm{means} \mathrm{that} \mathrm{total} \mathrm{dietary} \mathrm{concentrations} \mathrm{of} 105$ $\mathrm{mg} \mathrm{Zn} / \mathrm{Kg}$ diet was necessary to achieve normal productive performance in laying hens and further supplementation will be more expensive. The significant increases in egg production may be due to the important role of zinc in the synthesis and secretion of luteinizing hormone ( $\mathrm{LH})$ and follicle stimulating hormone $(\mathrm{FSH})$ as reported by Bedwal and Bahuguna (1994). Improving feed conversion for groups fed diets supplemented with zinc may be due to better efficiency of feed utilization resulted in higher egg production than those fed the un-supplemented control diet (Kout El-Kloub Moustafa et al., 2004).

Results in Table (4) showed that feed conversion during 28 -32 and 24 - 36 weeks of age, egg production during $24-28$ and 28 - 32 weeks of age, and egg mass during 24 - 28, 28 - 32 and 24 - 36 weeks of age were significantly $(\mathrm{P}<0.05$ or $\mathrm{P}<0.01)$ improved by interaction between dietary zinc source and their levels . Within each zinc source productive performance increased with increasing zinc level in the diet. It could be noticed that Bioplex $\mathrm{Zn}$ at a level of $105 \mathrm{mg} / \mathrm{Kg}$ diet recorded the best values of feed conversion, egg production and egg mass, while 
the lowest values were recorded with hens fed diets containing $\mathrm{ZnO}$ at the level of $35 \mathrm{mg} / \mathrm{Kg}$ diet. Kout El-Kloub Moustafa et al. (2004) found that, diet supplemented with $\mathrm{ZnO}$ at levels of 50 and $100 \mathrm{mg} / \mathrm{Kg}$ diet showed significantly $(\mathrm{P}<0.05)$ greater values of egg production than the control group.

\section{Reproductive performance:}

\section{1- Fertility and hatchability percentages:}

Results in Table (5) showed that fertile eggs \%, hatchability/total eggs \% and hatchability/ fertile eggs \% values were not significantly affected by zinc source in layers diets under heat stress. These results are impartial agreements with those of Kout El-Kloub Moustafa et al. (2004) who found that hatchability percentage of local laying hens was insignificantly improved by using all zinc sources ( $\mathrm{ZnO}$ or $\mathrm{Zn}$-methionine).

Layers fed diets contained $105 \mathrm{mg} \mathrm{Zn} / \mathrm{Kg}$ diet recorded the highest fertile eggs and hatchability/total eggs percentages among all treatments. Moreover these percentages were significantly $(\mathrm{P}<0.05)$ higher than those of layers fed $35 \mathrm{mg} \mathrm{Zn}$ $/ \mathrm{Kg}$ diet during the whole experimental period (Table 5). These results may be due to the improvement in egg and semen quality and higher sexual efficiency traits of the cocks treated with increasing level of zinc under heat stress. Similarly, Namra et al. (2008) suggested that, zinc supplementation as zinc-methionine at higher levels than that of NRC (1994) recommendations improved fertility of Japanese layer quails.

Fertile eggs (\%) and hatchability/total eggs (\%) values of Inshas laying hens were significantly $(\mathrm{P}<0.05)$ influenced by interaction between dietary $\mathrm{Zn}$ source and $\mathrm{Zn}$ level at 36 weeks of age as shown in Table 5. Inshas layer fed 105 mg Bioplex $\mathrm{Zn} / \mathrm{Kg}$ diet had higher fertile eggs (\%), hatchability/total eggs $\%$ and hatchability/fertility eggs $\%$ values as compared with other treatments. However, $\mathrm{Zn}$ source, levels and their interactions had no significant effect on hatchability/ fertile eggs (\%) (Table 5).

\section{2- Semen characteristics:}

Semen ejaculate volume $(\mathrm{ml})$, percentages of sperm motility and spermcell concentration of cocks fed diets contained Bioplex $\mathrm{Zn}$ were significantly $(\mathrm{P}<0.05)$ higher than those of cocks fed $\mathrm{Zn}$ oxide under heat stress as shown in Table 6. However, dead spermatozoa showed a reverse trend. Kout El-Kloub Moustafa et al. (2004) reported similar results. They found that addition of 100 and $150 \mathrm{mg} \mathrm{Zn}-\mathrm{Met} / \mathrm{Kg}$ or $100 \mathrm{mg} \mathrm{ZnO} / \mathrm{Kg}$ diet significantly $(\mathrm{P}<0.05)$ improved some semen quality measurements (ejaculate volume, mass motility, advanced motility and sperm concentration) of cocks. 
Table 5. Fertility and hatchability percentages $(\bar{x} \pm S E)$ of Inshas layers as affected by different sources and levels of dietary zinc and their interactions at 36 weeks of age.

\begin{tabular}{|c|c|c|c|c|}
\hline \multicolumn{2}{|c|}{ Items } & $\begin{array}{l}\text { Fertile } \\
\text { eggs } \\
(\%) \\
\end{array}$ & $\begin{array}{l}\text { Hatchability/t } \\
\text { otal Eggs (\%) }\end{array}$ & $\begin{array}{c}\text { Hatchability/ } \\
\text { fertile eggs } \\
(\%)\end{array}$ \\
\hline \multirow{3}{*}{\multicolumn{2}{|c|}{$\begin{aligned} \text { Zinc } & \text { sources } \\
& \text { Zinc oxide } \\
& \text { Bioplex } \mathrm{Zn}\end{aligned}$}} & NS & $\mathbf{N S}$ & NS \\
\hline & & $81.67 \pm 1.78$ & $67.50 \pm 1.99$ & $82.61 \pm 1.48$ \\
\hline & & $85.42 \pm 1.99$ & $72.08 \pm 2.50$ & $84.28 \pm 1.81$ \\
\hline \multirow{2}{*}{\multicolumn{2}{|c|}{$\begin{array}{c}\text { Zinc level }(\mathrm{mg} / \mathrm{kg}): \\
35\end{array}$}} & $* *$ & $* *$ & $\mathbf{N S}$ \\
\hline & & $76.67 \pm 2.11^{\mathrm{b}}$ & $62.50 \pm 2.81^{c}$ & $81.54 \pm 3.08$ \\
\hline \multicolumn{2}{|c|}{70} & $83.33 \pm 2.47^{\mathrm{a}}$ & $67.50 \pm 2.50 \mathrm{bc}$ & $81.01 \pm 1.82$ \\
\hline \multicolumn{2}{|c|}{105} & $89.17 \pm 2.01^{\mathrm{a}}$ & $77.50 \pm 2.14^{\mathrm{a}}$ & $86.95 \pm 1.84$ \\
\hline \multicolumn{2}{|c|}{140} & $85.00 \pm 1.83^{\mathrm{a}}$ & $71.67 \pm 2.47^{\mathrm{ab}}$ & $84.28 \pm 1.99$ \\
\hline \multicolumn{2}{|c|}{ Interaction effects: } & $*$ & $*$ & $\mathbf{N S}$ \\
\hline $\begin{array}{c}\text { Zinc } \\
\text { sources }\end{array}$ & $\begin{array}{c}\text { Zinc levels } \\
(\mathrm{mg} / \mathrm{kg})\end{array}$ & & & \\
\hline \multirow{4}{*}{ Zinc oxide } & 35 & $75.00 \pm 2.89^{c}$ & $60.00 \pm 2.89^{c}$ & $80.08 \pm 3.45$ \\
\hline & 70 & $81.67 \pm 4.41^{\mathrm{abc}}$ & $66.67 \pm 4.41^{\mathrm{bc}}$ & $81.67 \pm 3.47$ \\
\hline & 105 & $86.67 \pm 1.67^{\mathrm{ab}}$ & $73.33 \pm 1.67^{\mathrm{ab}}$ & $84.64 \pm 1.82$ \\
\hline & 140 & $83.33 \pm 1.67^{\mathrm{abc}}$ & $70.00 \pm 2.89^{\mathrm{bc}}$ & $84.07 \pm 3.80$ \\
\hline \multirow{4}{*}{ Bioplex Zn } & 35 & $78.33 \pm 3.33^{b c}$ & $65.00 \pm 5.00^{b c}$ & $83.01 \pm 5.78$ \\
\hline & 70 & $85.00 \pm 2.89^{a b c}$ & $68.33 \pm 3.33 \mathrm{bc}$ & $80.35 \pm 2.03$ \\
\hline & 105 & $91.67 \pm 3.33^{\mathrm{a}}$ & $81.67 \pm 1.67^{\mathrm{a}}$ & $89.27 \pm 2.86$ \\
\hline & 140 & $86.67 \pm 3.33^{\mathrm{ab}}$ & $73.33 \pm 4.41^{\mathrm{ab}}$ & $84.49 \pm 2.28$ \\
\hline
\end{tabular}

Means having different letters at the same row are significantly $(\mathrm{P} \leq 0.05)$ different.

$*=\mathrm{P}<0.05 ; * *=\mathrm{P}<0.01 ; \mathrm{NS}=$ Not significant.

Results in (Table 6) showed that semen ejaculate volume (ml), percentages of sperm motility and sperm cell concentration were significantly $(\mathrm{P}<0.05)$ higher cocks fed $105 \mathrm{mg} \mathrm{Zn} \mathrm{/Kg} \mathrm{diet} \mathrm{compared} \mathrm{with} \mathrm{those} \mathrm{of} \mathrm{cocks} \mathrm{fed} \mathrm{other} \mathrm{Zn}$ levels. While, dead spermatozoa and sperm abnormalities were significantly $(\mathrm{P}<0.05)$ decreased with increasing dietary $\mathrm{Zn}$ levels from 35 to $105 \mathrm{mg} / \mathrm{Kg}$ diet. However, hydrogen-ion concentration $(\mathrm{pH})$ was not significantly affected by different levels of $\mathrm{Zn}$ under heat stress. Similar trends were reported by Fathi et al. (2000) who 
found that dietary $\mathrm{Zn}$ supplementation caused an increase in semen volume of cocks. El-Masry et al. (1994) and Tharwat (1998) reported that dietary Zn supplementation showed greater proportion of progressively motile spermatozoa than those of control group. In this concern, Gunn et al., 1961 claimed that the normal levels of $\mathrm{Zn}$ are needed for the maturation of spermatozoa. Moreover, Underwood (1977) reported that, zinc deficiency resulted in a failure in normal sperm development, as well as, prostaticatrophy. It could be suggested that zinc may play an active role in the development of the flagellar system of the sperm which is reflected on sperm motility either via its passage and stay in the epididymis for complete maturation, or zinc may activate enzyme controlling flagellar system. Furthermore, the increasing of sperm motility may be due to increase in sperm cell concentration as a result of zinc supplementation.

The interaction between source and levels were significantly $(\mathrm{P}<0.05$ and $\mathrm{P}<0.01)$ as shown in Table (6). Semen ejaculate volume $(\mathrm{ml})$, percentages of sperm motility and sperm cell concentration of Inshas cocks fed $105 \mathrm{mg} \mathrm{Zn} / \mathrm{Kg}$ diet were significantly $(\mathrm{P}<0.05)$ higher than those of cocks fed either 35 or $70 \mathrm{mg} \mathrm{Zn} / \mathrm{Kg}$ diet. However, dead spermatozoa and sperm abnormalities showed a reverse trend as it decreased $(\mathrm{P}<0.05)$ with increasing $\mathrm{Zn}$ level from 35 to 70 and $105 \mathrm{mg} \mathrm{Zn} / \mathrm{Kg}$ diet. Inshas cocks fed $105 \mathrm{mg}$ Bioplex $\mathrm{Zn} / \mathrm{kg}$ diet showed an increase in sperm cell concentration and decrease in dead sperm percentage as compared with other treatment groups which led to improve the positive and direct effect on the viability of sperm and consequently affect the rate of cock fertility.

\section{Blood hematological, biochemical parameters and zinc yolk in egg:}

Blood hematological, biochemical parameters and zinc yolk of Inshas layers as affected by different sources and levels of dietary $\mathrm{Zn}$ and their interactions are presented in Table 7. Heamoglobin, total protein, albumin, globulin, serum zinc and yolk zinc of layers were not affected by $\mathrm{Zn}$ source under heat stress. These results are in partial agreement with those reported by Kout ElKloub Moustafa et al. (2004) who found that total protein, albumin and globulin concentrations were insignificantly higher in laying hens fed $\mathrm{Zn}$-Met than in those fed $\mathrm{ZnO}$.

Heamoglobin, serum zinc and yolk zinc were higher and almost significant $(\mathrm{P}<0.05)$ for layers fed diets contained 105 or $140 \mathrm{Zn} \mathrm{mg} / \mathrm{kg}$ as compared with those of layers fed other levels of $\mathrm{Zn}$ at the end of experimental period Table 7. Whereas, total protein, albumin and globulin, were not significantly affected by different levels of $\mathrm{Zn}$. These results are in good agreement with those reported by El-Husseiny et al. (2008) they found that hemoglobin increased with increasing either levels of $\mathrm{Zn}(70,105,140$ and $175 \mathrm{mg} / \mathrm{Kg}$ diet $)$ or niacin $(30,150,300,450$ 
$\mathrm{mg} / \mathrm{Kg}$ diet). Abou EL-Wafa et al. (2003) demonstrated that blood plasma zinc was increased by increasing dietary zinc level of broiler chicks. Mohanna et al. (1999) found that plasma $\mathrm{Zn}$ concentration increased linearly with zinc dietary content and reached a plateau at $75 \mathrm{mg} / \mathrm{Kg}$ diet whereas the whole body zinc was saturated when the dietary zinc content was $90 \mathrm{mg} / \mathrm{Kg}$. Verheyen et al. (1990) recorded that zinc concentration in egg yolk was $90 \mathrm{ppm}$ at the 4th days for hens fed with a high-zinc diet (10,000 ppm zinc for 2 days followed by 5,000 ppm zincsupplement diet for 4 days). Also, Decuypere et al. (1988) observed an increase in zinc content of egg yolk from the 3rd day after the start of feeding hens with zinc oxide $(10,000,20,000$, or $30,000 \mathrm{mg} \mathrm{Zn} / \mathrm{Kg}$ ). Results in Table (7) showed that heamoglobin, serum zinc and yolk zinc of laying hens were significantly $(\mathrm{P}<0.05)$ influenced by interaction between dietary source and level of $\mathrm{Zn}$, whereas, total protein, albumin and globulin value were not significantly effected by that interaction at the end of experimental period.

\section{Immune response to sheep red blood cells (SRBC'S):}

Results of immune response to sheep red blood cells (SRBC'S) are presented in Table 7. Antibody titer against SRBC'S was significantly $(\mathrm{P}<0.05)$ higher for layers fed diets contained Bioplex $\mathrm{Zn}$ as compared with those fed Zinc oxide. These results are in full agreement with those reported by Ferket and Qureshi (1992) who found that zinc from Zn-Met has been shown to heighten cellular immunity in poultry over that of $\mathrm{Zn}$ from $\mathrm{Zn} \mathrm{SO} 4$ and $\mathrm{ZnO}$.

Layers fed the diet contained 105 and $140 \mathrm{mg} \mathrm{Zn} / \mathrm{Kg}$ diet showed significantly $(\mathrm{P}<0.05)$ higher immune response compared to the other levels Table 7. In this concern, Kidd et al. (1992) found that adding zinc in hen diet increased significantly the humeral immune response of progeny chicks. EL-Kaiaty et al. (2001) reported that 50 or $100 \mathrm{mg} \mathrm{Zn} / \mathrm{Kg}$ diet was more efficient in immune response than other levels (150 and $200 \mathrm{mg} \mathrm{Zn} / \mathrm{Kg}$ diet).

Interaction between dietary zinc source and levels showed significant effect for antibody titer against SRBC'S as shown in Table 7. Supplementation of Bioplex $\mathrm{Zn}$ to the diet at levels of 105 and $140 \mathrm{mg} / \mathrm{Kg}$ diet recorded the best immune response to SRBC titres values (without significant differences between the two levels), while $\mathrm{ZnO}$ at the level of $35 \mathrm{mg} / \mathrm{Kg}$ diet recorded the lowest one. Generally, Zinc from Bioplex Zn improved titer against SRBC'S better than Zinc from $\mathrm{ZnO}$. Bartlett and Smith (2003) reported that birds fed the high zinc level (181 $\mathrm{mg} / \mathrm{Kg}$ diet) engulfed more SRBC'S than the other diets (34 and $68 \mathrm{mg} / \mathrm{Kg}$ diet) for opsonized and unopsonized SRBC with opsonized SRBC having greater phagocytic activity. 
Economic efficiency (EEf):

Data presented in Table (8) indicated that Inshas layers fed the feeding diet containing Bioplex $\mathrm{Zn}$ recorded the best economic efficiency (EEf) value and the lowest feed cost required to produce number of eggs compared to those of layers fed zinc. These trends may be attributed to the reduction in feed intake and improving feed conversion. The best EEf value and lowest feed cost required to produce number of eggs were obtained with layers fed $105 \mathrm{mg} \mathrm{Zn} / \mathrm{Kg}$ as compared with other levels of $\mathrm{Zn}$. Regarding the interaction effect, results in Table (8) demonstrated that the best EEf value during the whole experimental period was obtained with birds fed diets containing Bioplex $\mathrm{Zn}$ and $105 \mathrm{mg} \mathrm{Zn/} \mathrm{Kg}$ diet and may be due to the better performance of this treatment. These results are generally in partial agreement with those reported by Abou zeid et al. (1999) and Abou EL Wafa et al. (2003) who mentioned that Zinc supplementation to broiler's diet may be beneficial to broiler's performance and EEf. El-Husseiny et al. (2008) found that

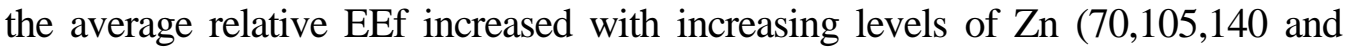
$175 \mathrm{mg} / \mathrm{kg}$ diet) and decreased with increasing levels of niacin $(30,150,300,450$ $\mathrm{mg} / \mathrm{kg}$ diet).

In conclusion, from the nutritional and physiological points of view it could be concluded that the use of organic zinc at the level of $105 \mathrm{mg} \mathrm{Zn} / \mathrm{Kg}$ diet improved the productive, reproductive performance and economic efficiency of Inshas strain from 24-36 weeks of age strain under hot summer condition in Egypt.

\section{REFERENCES}

Abou EL-Wafa, S.; Sayed, M.A.M.;Ali, S.A.and Abdallah,A.G.(2003). Performance and immune response of broiler chicks as affected by mithionine and zinc or commercial zinc-methionine supplementations. Egyptian Journal of Poult. Sci., 23 (3): 523-540.

Abou-Zeid, A. E.; Mohamed, F. F.; and EL-Soud, S. B. (1999). Impact of vitamin $\mathrm{C}$ and/or zinc supplementation on performance and immunity of broilers. Egyptian Journal of Poult. Sci., 19 (3): 635-655.

Ammerman, C.B.; Baker, D.H. and Lewis, A.J. (1995). Bioavailability of Nutrients for Animals: Amino Acids, Minerals, and Vitamins. Academic Press, San Diego, CA.

AOAC. (1990). Association of Official Analytical Chemists, Official Methods of Analysis, 15th Ed., Published by the AOAC, Washington, DC. USA. 
Bartlett, J. R. and Smith, M. O. (2003). Effects of different levels of Zinc on the performance and immunocompetence of broilers under heat stress. Poult. Sci., 82:1580-1588.

Bedwal, R.S. and Bahuguna, A. (1994). Zinc, copper, selenium in reproduction. Experientia, 50: 626- 640.

Cao, J.; Henry, P.R. and Guo, R. (2000). Chemical characteristics and relative bioavailability of supplemental organic zinc sources for poultry and ruminants. J. Anim. Sci., 78: 2039-2054.

Decuypere, E.; Helsen, J.; Van Gorp, S. and Verheysn, G. (1988). The use of high zinc diets as forced molting method: Effect on Zn uptake and egg $\mathrm{Zn}$ content. Archiv fureflii-gelkunde, 52: 245-251.

Donkoh, A. (1989). Ambient temperature: a factor affecting performance and physiological response of broiler chickens. International Journal of Biometeorol., 33: 259-265.

Duncan, D. B. (1955). The Multiple Range and Multiple F-Test. Biometrics, 11: $1-42$.

El-Husseiny, O.M.; Abd-Elsamee, M.O.; Omara, I.I. and Fouad, A.M. (2008). Effect of dietary zinc and niacin on laying hens performance and egg quality. International Journal of Poult. Sci., 7 (8):757-764.

El-Kaiaty, A. M.; Ragab, F. A. and Riad, S. A. (2001). The effect of dietary zinc and /or methionine on some productive and immunological response in two strains of chickens. Egyptian Journal Poult. Sci., 21(2):441-464.

El-Masry, K.A.; Nasr, A.S. and Kamal, T.H. (1994). Influence of season and dietary supplementation with selenium and vitamin $\mathrm{E}$ or zinc on some blood constituents and semen quality of New Zealand White rabbit males. World Rabbit Sci., 2:79-86.

Fathi, M. M.; Tharwat, E. E. and El-Hommosany, Y. M. (2000). Response of semen quality of naked neck cooks to zinc supplementation or GnRH injection. Egyptian Journal of Poult. Sci., 20 (4):1047-1064.

Ferket, P. R.; and Qureshi, M. A. (1992). Effect of level of inorganic and organic zinc and manganese on the immune function of turkey toms.Poult.Sci.,71 (Suppl.1):60 (Abstr.).

Ferket, P. R.; Nicholson, L.; Roberson, K. D. and Yoong, C. K. (1992). Effect of level of inorganic and organic zinc and manganese on the immune function of turkey toms. Poult. Sci., 71 (Suppl.1):60 (Abstr.).

Franco, J.D.J and Beck, M. M. (2007). Physiological changes to transient exposure to heat stress observed in laying hens. Poult. Sci., 86:538-544. 
Gunn, S.A.; Gould, C.T. and Anderson, W.A. (1961) Hormonal control of zinc in mature rate testis. Journal of Endocrinology., 23:37-45.

Hahn, J. D. and Baker, D. H. (1993) Growth and plasma zinc responses of young pigs fed pharmacologic levels of zinc. J. Anim. Sci., 71:3020-3024.

Innocenti, A.; Zimmerman, S.; Ferry, J.G; Scozzafava, A. and Supuran, C.T. (2004). Carbonic anhydrase inhibitors. Inhibition of the zinc and cobalt gammaclass enzyme from the archaeno methanosarcina thermophila with anions. Bioor. Med. Chem. Lett., 14: 3327-3331.

Karras, W. (1952). Waeme wasserbed and registratur, ihr entwicklung und anwendung. Deutschland Tieraezlt-Wochenschr, 59: 60-62 and 68-69.

Kidd, M. T.; Anthony, N. B. and Lee, S. R. (1992). Progeny performance when dams and chicks are fed supplemental zinc. Poult. Sci., 71:1201.

Kidd, M. T.; Qureshi, M. A.; Ferket, P. R. and Thomas, L. N. (2000). Turkey hen zinc source affects progeny immunity and disease resistance. Journal of Appl. Poult. Res., 9:414-423.

Kim, W.K. and Patterson, P.H. (2005). Effects of dietary zinc supplementation on hen performance, ammonia volatilization and nitrogen retention in manure. Journal of Environ. Sci. Health, 40: 675-686.

Kout El-Kloub, M. E.; Moustafa, R. A.; Hassan, E. H.; El.Ganzory, E.A. and El-Abd, E.A. (2004). Effect of different sources and levels of zinc on the performance of local laying hens. Egyptian Journal Poult. Sci., 24 (2): 369-385.

Lake, P. E. and Stewart, J. M. (1978). Artificial Insemination in Poultry. Agric. Fish. Fd. Bulletin, No. 213. H. M. Stationery Office, London.

Luecke, R. W.; Simonel, C. E. and Farker, D. J. (1978). The effect of restricted dietary intake on the antibody mediated response of the zinc deficient A/J mouse. Journal of Nutr., 8:881.

Mañón, A.; Cantor, A.; Pescatore, A.; Ford, M.; Gillespie, H. and Daley, M. (2005). Influence of dietary supplementation of organic minerals and phytase on mineral concentration in manure of replacement pullets. Poult. Sci., 84 (Suppl. 1): 85.

Marai,I.F.M., Bahgat, L.B. Shalaby, T.H. and Abdel-Hafez, M.A. (2000). Fattening performance, some behavioral traits and physiological reactions of males lambs fed concentrates mixture alone with or without natural clay, under hot summer of Egypt. Annals of Arid Zonne, 39 (4):449-460

Mohanna, C.; Carre, B. and Nys, Y. (1999). Effect of dietary zinc content and sources on growth, body zinc deposition and retention zinc excretion and immune on response in chickens. Br. Poult. Sci., 40:108-114. 
Namra, M. M. M; Fayek, H. M.; and Hala M. Abdel Wahed (2008). Evaluation of different sources of dietary zinc supplementation for Japanese quails: 1- Growth performance. Egyptian Poultry Science, 28 (4): 1023-1041.

NRC, (1994). National Research Council, Nutrient requirements of poultry. $9^{\text {th }} \mathrm{Ed}$, National Academic of Science. Washington, DC. USA.

Rashidi, A. A.; Gofrani,Y. I.; Khatibjoo,A. and Vakili, R. (2010). Effect of dietary fat, vitamin $\mathrm{E}$ and zinc on immune response and blood parameters of broiler reared under heat stress. Journal of Poultry Sci., 3 (2):32-38.

Sahin, K. and Kucuk, O. (2003). Zinc supplementation alleviates heat stress in laying Japanese quail. Journal of Nutr., 133: 2808-2811.

Sahin, K.; Sahin, N. ; Kucuk, O. ; Hayirli, A. and Prasad, A. S. (2009). Role of dietary zinc in heat- stressed poultry: A review. Poult. Sci., 88:21762183.

Salgueri, M. J.; Zubillaga, M.; Lysionek, A.; Sarabia, M. I.; Caro, R.; De Paoli, T.; Hager, A.; Weill, R. and Boccio, J. (2000). Zinc as essential micronutrient:a review. Nutr. Research, 20: 737-755.

SAS Institute, (2003). SAS User's Guide: Statistics. Version 8.2, SAS Institute Inc., Cary, NC.

Tharwat, E. E. (1998). The use of zinc sulfate to improve semen characteristics and fertility of New Zealand White rabbit bucks during hot season. 7th Conf. Agric. Development Research, Ain Shams Univ., Cairo, 15-17 Dec., PP. 757-770.

Underwood, E.J. (1977). Trace Elements in Human and Animals Nutrition. $4^{\text {th }}$ Ed.Academic Press, New York, Sanfransisco and London.

Verheyen, G.; Helsen, J. and Decuyper, E. (1990). Accumulation of zinc in egg yolk, ovarian follicles and organs after forced resting by high dietary zinc. Br. Poult. Sci., 31: 147-154.

Yamamoto, Y.; and Glick, B. (1982). A comparison of the immune response between two lines of chickens selected for differences in the weight of the bursa of fabricius. Poult. Sci., 61:21-29.

Wedekind, K.J., Hortin, A.E. and Baker, D.H.: (1992). Methodology for assessing zinc bioavailability: efficacy estimates for zinc-methionine, zinc sulfate, and zinc oxide. Journal of Anim. Sci., 70:178-187. 


\section{بعض الصفات الفسيولوجية والتناسلية لسلالة انشاص المحلية والمتأثزة بإضافة الزنك إلي الغذاء تحت ظروف الصيف الحار في مصر.}

\section{احمد محمد احمد بعيلش"، وحيد عزت"، صبري موسي محمود موسي" ، حسن عبد الكريم

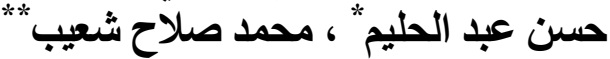

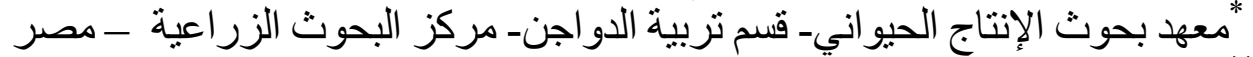

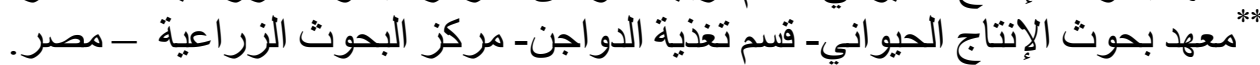

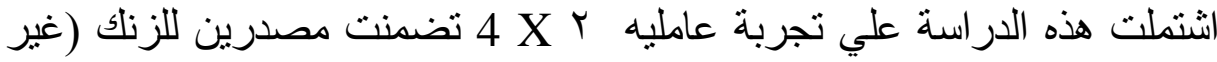

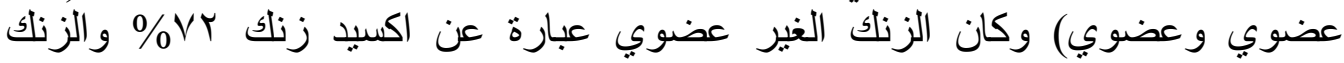

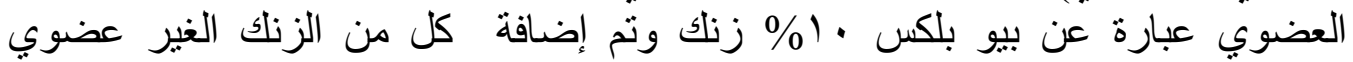

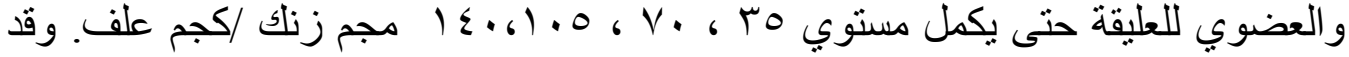

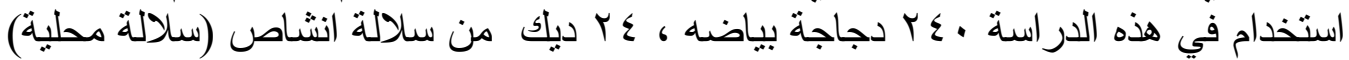

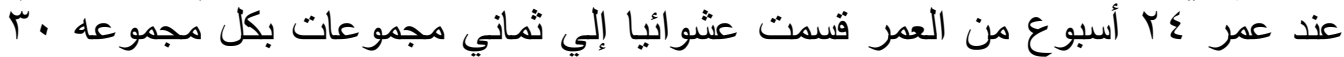

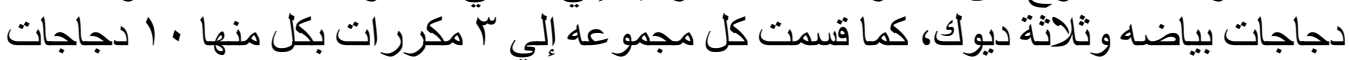

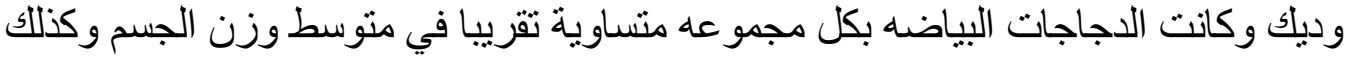

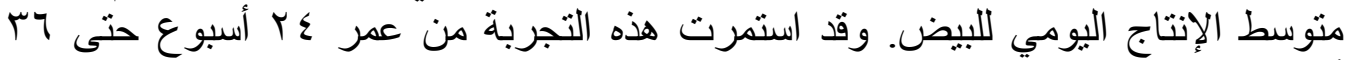

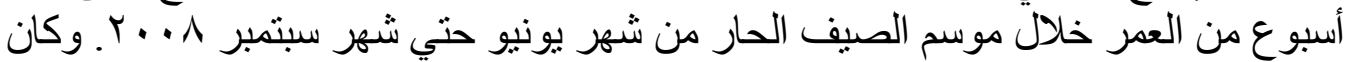

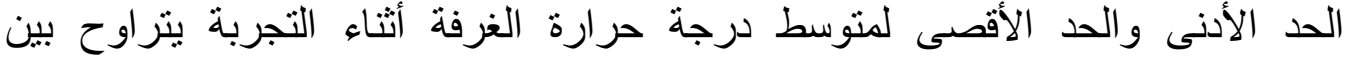

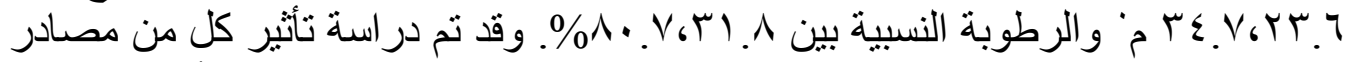

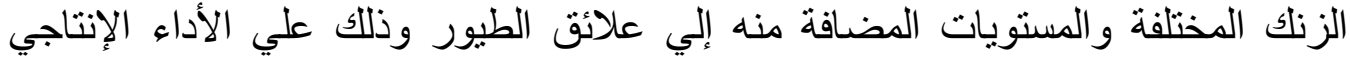
و التناسلي و الاستجابة المناعية وكذلك الكفاءة الاقتصادية.

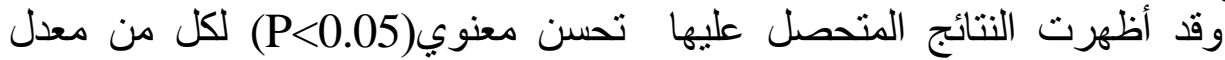

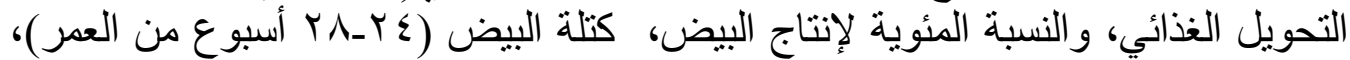

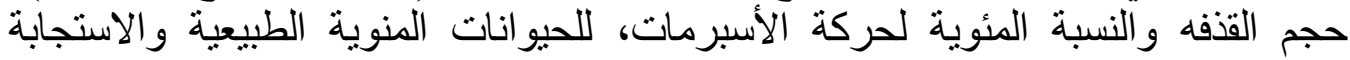

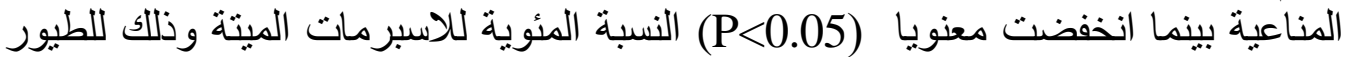

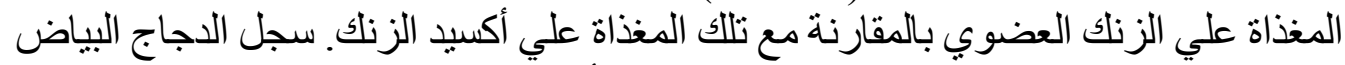

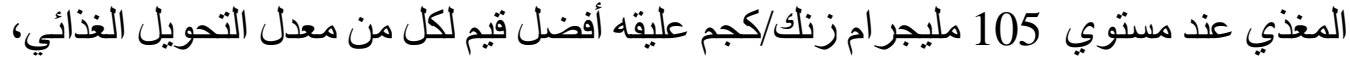
النسبة المئوية لإنتاج البيض، كتلة البيض، النسبة المئوية للبيض المخصب، النسبة النئية النئية 


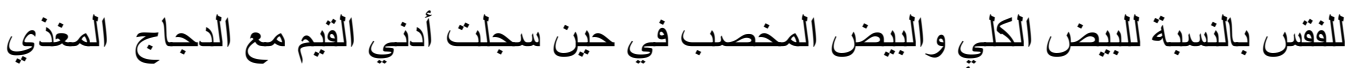

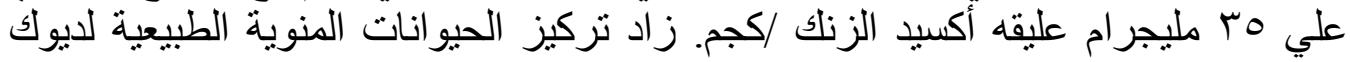

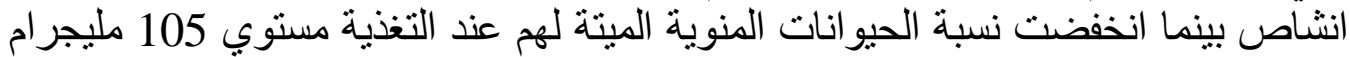

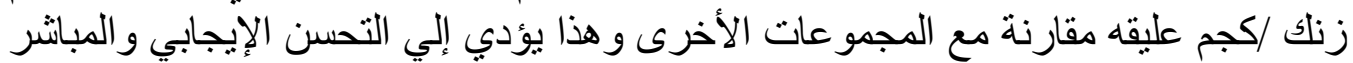

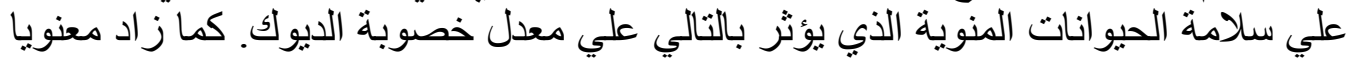

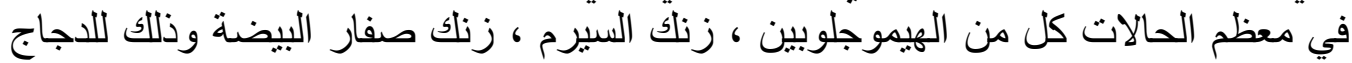

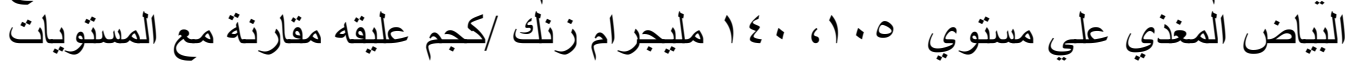

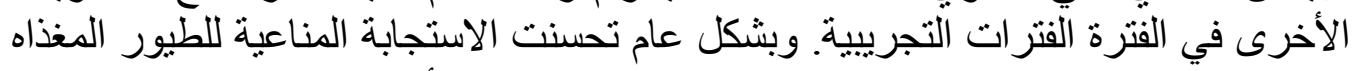

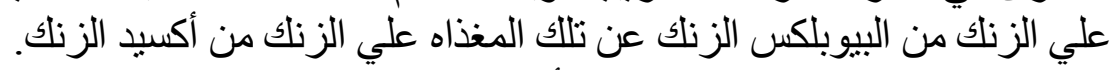

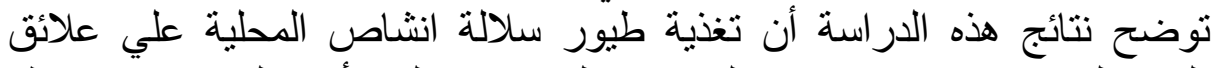

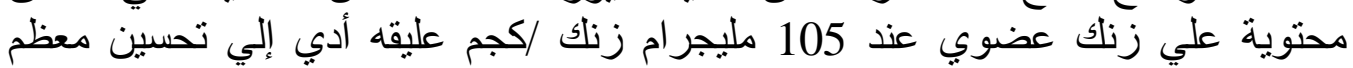

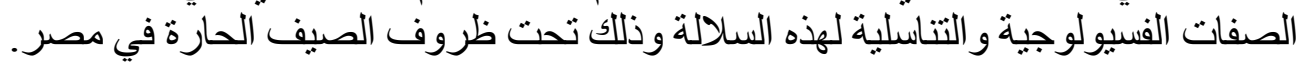

